Pak. J. Biotechnol. Vol. 18 (1-2) 31- 36 (2021) pISSN: 1812-1837 eISSN 2312-7791

www.pjbt.org http://doi.org/10.34016/pjbt.2021.18.1-2.31

\title{
PHYSICO-CHEMICAL AND ORGANOLEPTIC CHARACTERISTICS OF BISCUITS ENRICHED WITH DATE POWDER
}

\author{
Ayaz Ali ${ }^{1}$, Akhtiar $\mathrm{Ali}^{3}$, Shagufta Naz ${ }^{2}$, Riaz Ali ${ }^{1}$, Zulfiqar Ali Mastoi ${ }^{1}$, Majid Ali $^{2}$, Nazia Bashir ${ }^{2}$, \\ Nighat Din ${ }^{1}$, Salman Ali ${ }^{4}$. \\ ${ }^{1}$ Department Agriculture and cooperative Department Balochistan (Research wing), ${ }^{2}$ Agriculture Officer \\ Agriculture Department balochitsan. ${ }^{3}$ P.hd Schallor Beijing university China. \\ ${ }^{4}$ Agriculture University Tando Jam Sindh. *Corresponding Author Email: ghulamnabigola@gmail.com
}

Article received 27.7.2021, $\quad$ Revised 1.8.2021, Accepted 11.8.21

\begin{abstract}
:
The study was carried out during 2018 at laboratory of Institute of Food Sciences and Technology, Sindh Agriculture University, Tandojam to evaluate the physico-chemical and organoleptic characteristics of biscuits enriched with date powder. The treatments included: $\mathrm{T} 1=0 \%$ without date powder (control), $\mathrm{T} 2=50 \%$ date powder and $\mathrm{T} 2=100 \%$ dates powder. Some chemical parameters were studied which included moisture (\%), ash (\%), TSS ( ${ }^{\circ} \mathrm{Brix}$ ), $\mathrm{pH}$ value, vitamin $\mathrm{C} \mathrm{mg} \mathrm{g}^{-1}$, protein (\%), carbohydrates (\%), fat (\%) and crude fiber (\%) per $100 \mathrm{mg}$. The control (T1) with $0 \%$ date powder (control) resulted in $2.44 \%$ moisture, $0.30 \%$ ash, $9.50^{\circ}$ Brix total soluble solids, $5.60 \mathrm{pH}$ value, $16.92 \mathrm{mg} / 100 \mathrm{~g}$ vitamin C, $32.61 \%$ fat, 0.02 per $100 \mathrm{mg}$ crude fiber, $18.59 \%$ protein and $44.37 \%$ carbohydrate. The sensorial analysis indicates that numerical high score of color (8.36), flavor (8.60), texture (7.86), taste (8.50) and overall acceptability (8.06) was recorded in biscuits enriched with $100 \%$ dates powder followed by biscuits with $50 \%$ date powder with average score of color (7.46), flavor (7.53), texture (7.60), taste (7.46) and overall acceptability $(7.56$
\end{abstract}

\section{Keys: physico-chemical, organoleptic characteristics of biscuits}

\section{INTRODUCTION}

Biscuits have always been a popular, appealing food product due to their thrilling and textured features, compactness, convenience and cost competitiveness. They have lower moisture content than cakes and bread and are protected from microbiological dam-age and have a longer shelf life. Usman et al., (2015) reported that it is high in calories, low proteins, low in fibre and hence, are not considered in healthy food category especially for aged, diabetic and obese people, significant amount of fat which is not good for peoples which diabetics (Mishra and Chandra, 2012). Bakery products usually high in carbohydrate, fat and calorie, but low in fiber content (Mishra and Chandra, 2012). Date is an important fruit tree for semiarid and hot arid regions of the country and highly nutritious and favorite fruit throughout the country. Besides fresh consumption, several value-added products viz., dry dates (chhuhara), soft date (pind khajoor), jam, syrup, chutney, beverages, pickle (Singh and Dhandar, 2007), Date fruits provide abundant quantities of sugar, iron, potassium, calcium and nicotinic acid and small amounts of protein, copper, magnesium, chlorine, sulphur and vitamins. The pulp of mature date fruits contains about $80 \%$ sugars on dry weight basis, which being easily digestive, provide a ready source of energy to the human body. Such fruits can provide about 3,150 calories per kg. In Pakistan, date palm fruits are harvested from mid-June to August at doka or khalal stage (hard ripe yellow, red or dark red color) because of lack of early maturing varieties. Due to short shelf life, fresh fruits have to be utilized immediately after harvest. In our country, Kachchh region of Gujarat has maximum area under this crop (1668 ha) with annual production of 1,23,490 tons, where maximum fruits are harvested at doka stage (Muralidharan et al., 2008). The flesh of a fully ripe date consists of two-third sugar and one-quarter water, the rest being mainly cellulose, pectin, vitamin and ash. The date considered as a nutritious fruit (Anwarul et al., 2012).

\section{MATERIALS AND METHODS}

The study was carried out to determine physicochemical and organoleptic characteristics of biscuits enriched with date powder experiment was conducted at the laboratories of Institute of Food Science and Technology, Tando Jam Agriculture University Sindh, during 2018.

Collection of samples: Common dehydrated Aseel date variety were collected from the Khairpur market and brought to the laboratory of the Institute of Food Science and Technology, Sindh Agriculture University, Tandojam. Dehydrated dates were grinded in grinder machine packed and labeled and then stored at ambient temperature $\left(30 \pm 4^{\circ} \mathrm{C}\right)$ until use.

Development of biscuits using date powder: Three types of biscuits were prepared by using different ration of dehydrated dates powder. TypeI biscuit was prepared by using $0 \%$ dates powder, Type-II by $50 \%$ dates powder and Type-III by 
using $100 \%$ dates powder. Other ingredients used and method of preparation of biscuit is depicted in Table 1-3

Table 1: Ingredients used and method of preparation each product (T1)

\begin{tabular}{|c|c|}
\hline $\operatorname{gg}$ & $\begin{array}{lll}1 & \text { Sieve refined flour an }\end{array}$ \\
\hline Sugar & $100 \mathrm{~g}$ date powder toget \\
\hline Butter & $133 \mathrm{~g}$ Butter, sugar and $\mathrm{N}$ \\
\hline Vanilla powder & $2 \mathrm{~g}$ powder Add soc \\
\hline Baking powder & bicarbonate and salt. \\
\hline Maida & 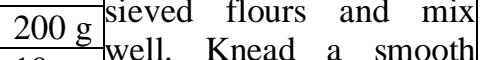 \\
\hline Milk powder & $10 \mathrm{~g}$ dough keep for 30 \\
\hline Salt & $\begin{array}{l}3 \mathrm{~g} \text { Again, knead dou } \\
\text { Make biscuits and bake } \\
160^{\circ} \mathrm{C} \text { for } 30 \text { minutes. }\end{array}$ \\
\hline
\end{tabular}

Table 2: Ingredients used and method of preparation each product (T2)

\begin{tabular}{|c|c|c|}
\hline gg & 1 & ed flour and $\mathrm{da}$ \\
\hline ugar & $50 \mathrm{~g}$ & gether. Butter, Da \\
\hline Date po & $50 \mathrm{~g}$ & Milk powd \\
\hline Butter & $133 \mathrm{~g}$ & bica \\
\hline Tanill & $2 \mathrm{~g}$ & ved \\
\hline g powder & $1 \frac{1}{2}$ & $\begin{array}{l}\text { W } \\
k e\end{array}$ \\
\hline aid & $200 \mathrm{~g}$ & e biscui \\
\hline $1 \mathrm{k}$ & $10 \mathrm{~g}$ & $160^{\circ} \mathrm{C}$ for 30 minutes. \\
\hline & & \\
\hline
\end{tabular}

Table 3: Ingredients used and method of preparation ach product (T3)

\begin{tabular}{|c|c|c|}
\hline Egg & 1 & Sieve refined flour and da \\
\hline Sugar & $100 \mathrm{~g}$ & wder together. Butter, su \\
\hline Butter & $133 \mathrm{~g}$ & Milk powder Add sodi \\
\hline Vanilla powder & $2 \mathrm{~g}$ & bicarbonate and salt. \\
\hline Baking powder & $1 \frac{1}{2}$ & ved flours and mix \\
\hline Maida & $200 \mathrm{~g}$ & $\begin{array}{l}\text { ad a smooth dough } \mathrm{ke} \\
30 \text { min Again kne }\end{array}$ \\
\hline Milk powder & $10 \mathrm{~g}$ & $\begin{array}{l}\text { tor } 30 \text { min. Again, kne } \\
\text { dough. Make biscuits and b }\end{array}$ \\
\hline Salt & $3 \mathrm{~g}$ & at $160^{\circ} \mathrm{C}$ for 30 minutes. \\
\hline
\end{tabular}

Preparation of samples for Physico-chemical and sensorial analysis: The prepared biscuits were analyzed, such as moisture (\%), ash (\%), TSS, pH, protein $(\%)$, total carbohydrates $(\%)$, fat $(\%)$, crude fiber and titratable acidity (\%) were determined using the official methods of AOAC (2000) and Vitamin C (ascorbic Acid) was James (1995) and Mazumdar and Majumder (2003). The prepared biscuits were coded and evaluated for sensorial analyses such as flavor, taste, texture, color consistency and overall acceptability.

Statistical analysis: The data was subjected to an analysis of variance (ANOVA) described by Steel et al., (1996).

\section{RESULTS}

The data on the above parameters are presented in (Tables 4-14) and analysis of variance as seen in
Tables 4-14. Moisture 10.27, Protein 1.89, Fat 0.39 , Fiber 9.83, Ash 0.04, pH 5.62, Total acidity0.02, Vitamin C 0.02, Carbohydrate 5.75.

Table 4: Composition of dehydrated dates powder $(\%)$

\begin{tabular}{|l|c|c|c|c|}
\hline Parameters & RI & RII & RIII & Mean \\
\hline Moisture & 10.00 & 10.50 & 10.30 & $\mathbf{1 0 . 2 7}$ \\
\hline Protein & 1.70 & 2.12 & 1.84 & $\mathbf{1 . 8 9}$ \\
\hline Fat & 0.42 & 0.36 & 0.38 & $\mathbf{0 . 3 9}$ \\
\hline Fiber & 9.60 & 10.10 & 9.80 & $\mathbf{9 . 8 3}$ \\
\hline Ash & 0.044 & 0.033 & 0.040 & $\mathbf{0 . 0 4}$ \\
\hline pH & 5.60 & 5.57 & 5.68 & $\mathbf{5 . 6 2}$ \\
\hline Total acidity & 0.013 & 0.025 & 0.020 & $\mathbf{0 . 0 2}$ \\
\hline Vitamin C & 0.012 & 0.022 & 0.017 & $\mathbf{0 . 0 2}$ \\
\hline Carbohydrate & 5.50 & 6.00 & 5.75 & $\mathbf{5 . 7 5}$ \\
\hline
\end{tabular}

Moisture (\%): It is evident from the results that the maximum biscuits moisture $(3.65 \%)$ when the biscuits treated with $100 \%$ dates powder, followed by $50 \%$ date powder with $2.92 \%$ moisture. However, the minimum moisture $(2.44 \%)$ was observed with $0 \%$ without date powder (control). It was found that $100 \%$ dates powder was optimum level for biscuits so far the moisture (\%). The LSD test demonstrated that the differences in moisture $(\%)$ different date powder levels were significant $(\mathrm{P}<0.0)$.

Table 5: Effect of different ratio of date powders on moisture (\%) of biscuits

\begin{tabular}{|l|l|l|l|l|}
\hline Treatments & RI & RII & RIII & Mean \\
\hline T1 & 2.55 & 2.33 & 2.44 & 2.44 C \\
\hline T2 & 2.84 & 3.00 & 2.92 & $2.92 ~ B$ \\
\hline T3 & 3.81 & 3.50 & 3.66 & $3.65 ~ A$ \\
\hline S.E. \pm & \multicolumn{4}{|c|}{0.0972} \\
\hline
\end{tabular}

LSD $0.05 \quad 0.2379$

$\mathrm{T} 1=0 \%$ without date powder (control);

$\mathrm{T} 2=50 \%$ date powder

$\mathrm{T} 3=100 \%$ dates powder

Ash (\%): It is evident from the results that the maximum biscuits ash $(0.69 \%)$ when the biscuits treated with $100 \%$ dates powder, followed by $50 \%$ date powder with $0.36 \%$ ash. However, the minimum ash $(0.30 \%)$ was observed with $0 \%$ without date powder (control). It was found that $0 \%$ without date powder (control) was optimum level for biscuits so far the ash (\%). The LSD test demonstreated that the differences in ash $(\%)$ different date powder levels were significant $(\mathrm{P}<0.05)$

Table 6: Effect of different ratio of date powders on ash (\%) of biscuits

\begin{tabular}{|l|c|c|c|l|}
\hline Treatments & RI & RII & RIII & Mean \\
\hline T1 & 0.37 & 0.35 & 0.36 & 0.30 C \\
\hline T2 & 0.29 & 0.32 & 0.30 & 0.36 B \\
\hline T3 & 0.66 & 0.72 & 0.69 & 0.69 A \\
\hline
\end{tabular}



S.E. \pm
0.0166
LSD 0.05
0.0405

$\mathrm{T} 1=0 \%$ without date powder (control);

$\mathrm{T} 2=50 \%$ date powder

$\mathrm{T} 3=100 \%$ dates powder

Total soluble solids (Brix): Results shows that the maximum biscuits total soluble solid $\left(11.71^{\circ}\right.$ Brix) observed when the biscuits treated with 100 $\%$ dates powder, followed by $50 \%$ date powder with $9.72^{\circ}$ Brix total soluble solid. However, the minimum total soluble solid $\left(9.50^{\circ}\right.$ Brix $)$ was observed with $0 \%$ without date powder (control). It was found that $0 \%$ without $100 \%$ dates powder was optimum level for biscuits so far the total soluble solid ( ${ }^{\circ}$ Brix). The LSD test demonstrated that the differences in total soluble solid ( ${ }^{\circ}$ Brix) differrent date powder levels were significant $(\mathrm{P}<0.05)$.

Table 7: Effect of different ratio of date powders on Total soluble solids $\left({ }^{\circ}\right.$ Brix) of biscuits

\begin{tabular}{|l|c|c|c|l|}
\hline Treatments & RI & RII & RIII & Mean \\
\hline T1 & 9.49 & 9.51 & 9.50 & $\mathbf{9 . 5 0 ~ C}$ \\
\hline T2 & 9.70 & 9.74 & 9.72 & $\mathbf{9 . 7 2 ~ B ~}$ \\
\hline T3 & 1.70 & 11.73 & 11.71 & $\mathbf{1 1 . 7 1 ~ A ~}$ \\
\hline S.E. \pm & 0.0128 \\
LSD 0.05 & \multicolumn{5}{|c|}{0312}
\end{tabular}

$\mathrm{T} 1=0 \%$ without date powder (control);

$\mathrm{T} 2=50 \%$ date powder

$\mathrm{T} 3=100 \%$ dates powder

pH value (\%): It is evident from the results that the maximum biscuits $\mathrm{pH}$ value (5.70) was observed when the biscuits treated with $100 \%$ dates powder, followed by $50 \%$ date powder with 5.63 $\mathrm{pH}$ value. However, the minimum $\mathrm{pH}$ value (5.60) was observed with $0 \%$ without date powder (control). It was found that $100 \%$ dates powder was optimum level for biscuits so far the $\mathrm{pH}$ value. The LSD test demonstrated that the differences in $\mathrm{pH}$ value different date powder levels were significant $(\mathrm{P}<0.05)$.

Table 8: Effect of different ratio of date powders on pH of biscuits

\begin{tabular}{|c|c|c|c|c|}
\hline Treatments & RI & RII & RIII & Mean \\
\hline $\mathrm{T} 1$ & 5.61 & 5.60 & 5.60 & $5.60 \mathrm{C}$ \\
\hline $\mathrm{T} 2$ & 5.62 & 5.64 & 5.63 & $5.63 \mathrm{~B}$ \\
\hline T3 & 5.69 & 5.72 & 5.70 & $5.70 \mathrm{~A}$ \\
\hline S.E. \pm & \multicolumn{4}{|c|}{9.0273} \\
\hline LSD 0.05 & \multicolumn{4}{|c|}{0.0221} \\
\hline
\end{tabular}

$\mathrm{T} 1=0 \%$ without date powder (control);

$\mathrm{T} 2=50 \%$ date powder

$\mathrm{T} 3=100 \%$ dates powder

Vitamin $\mathbf{C}\left(\mathbf{m g} / \mathbf{1 0 0 g}^{-\mathbf{1}}\right)$ : It is evident from the results that the maximum biscuits vitamin $\mathrm{C}$ $\left(20.68 \mathrm{mg} / 100 \mathrm{~g}^{-1}\right)$ was noted when the biscuits treated with $100 \%$ dates powder, followed by $50 \%$ date powder with $20.68 \mathrm{mg} / 100 \mathrm{~g}^{-1}$ vitamin $\mathrm{C}$. However, the minimum vitamin $\mathrm{C}(16.92 \mathrm{mg} /$ $100 \mathrm{~g}^{-1}$ ) was observed with $0 \%$ without date powder (control). It was found that $100 \%$ dates powder was optimum level for biscuits so far the vitamin C. The LSD test demonstrated that the differences in vitamin $\mathrm{C}$ was noted in date powder levels which is non- significantly $(\mathrm{P}>0.05)$.

Table 9: Effect of different ratio of date powders on vitamin $\mathrm{C}\left(\mathrm{mg} / \mathbf{1 0 0 g}^{-1}\right)$ of biscuits

\begin{tabular}{|c|c|c|c|c|}
\hline Treatments & RI & RII & RIII & Mean \\
\hline T1 & 18.81 & 15.04 & 16.92 & $\mathbf{1 6 . 9 2 ~ C}$ \\
\hline T2 & 17.80 & 19.00 & 20.22 & $\mathbf{1 9 . 0 1}$ B \\
\hline T3 & 22.56 & 18.80 & 20.68 & $\mathbf{2 0 . 6 8 ~ A}$ \\
\hline S.E. \pm & \multicolumn{5}{|c}{1.5364} \\
LSD 0.05 & \multicolumn{5}{|c}{3.7594}
\end{tabular}

$\mathrm{T} 2=50 \%$ date powder

T3 $=100 \%$ dates powder

Fat \%: It is evident from the results table 10 that the maximum biscuits fat $(34.19 \%)$ noted when the biscuits treated with $100 \%$ dates powder, followed by $50 \%$ date powder with $33.79 \%$ fat. However, the mini-mum fat $(32.61 \%)$ was observed with $0 \%$ without date powder (control). It was found that $100 \%$ dates powder was optimum level for biscuits so far, the fat. The LSD test demonstrated that the percentage of fat different in date powder levels were non-significantly $(\mathrm{P}>0.05)$.

Table 10: Effect of different ratio of date powders on fat $(\%)$ of biscuits

\begin{tabular}{|c|c|c|c|c|}
\hline Treatments & $\mathbf{R I}$ & RII & RIII & Mean \\
\hline $\mathrm{T} 1$ & 32.13 & 33.10 & 32.61 & 32.61 A \\
\hline $\mathrm{T} 2$ & 32.85 & 34.74 & 33.79 & 33.79 A \\
\hline T3 & 35.30 & 33.09 & 34.19 & 34.19 A \\
\hline \multicolumn{2}{|l|}{ S.E. \pm} & \multicolumn{2}{|c|}{0.7225} & \\
\hline \multicolumn{2}{|l|}{ LSD 0.05} & \multicolumn{2}{|c|}{1.7680} & \\
\hline
\end{tabular}

Crude fiber $\left(100 \mathrm{mg}^{-1}\right)$ : It is evident from the results that the maximum biscuits crude fiber $\left(0.04 \% 100 \mathrm{mg}^{-1}\right)$ noted when the biscuits treated with $100 \%$ dates powder, followed by $50 \%$ date powder with $0.03 \% 100 \mathrm{mg}^{-1}$ crude fiber. However, the minimum crude fiber $\left(0.02100 \mathrm{mg}^{-1}\right)$ was observed with 50\% date powder. It was found that $100 \%$ dates powder was optimum level for biscuits so far the crude fiber. The LSD test demonstrated that the differences in crude fiber different date powder levels were significantly $(\mathrm{P}<0.05)$. 
Table 11: Effect of different ratio of date powders on crude fiber $\left(100 \mathrm{mg}^{-1}\right)$ of biscuits

\begin{tabular}{|l|c|c|c|c|}
\hline Treatments & RI & RII & RIII & Mean \\
\hline T1 & 0.015 & 0.020 & 0.017 & $\mathbf{0 . 0 2}$ C \\
\hline T2 & 0.035 & 0.030 & 0.032 & $\mathbf{0 . 0 3 ~ B}$ \\
\hline T3 & 0.040 & 0.045 & 0.042 & $\mathbf{0 . 0 4} \mathbf{A}$ \\
\hline S.E. \pm & \multicolumn{4}{|c}{3.84903} \\
LSD 0.05 & 9.41803
\end{tabular}

$\mathrm{T} 1=0 \%$ without date powder (control);

$\mathrm{T} 2=50 \%$ date powder

$\mathrm{T} 3=100 \%$ dates powder

Protein (\%): It is evident from the results (Table 11) that the maximum biscuits protein $(7.65 \%)$ noted when the biscuits treated with $100 \%$ dates powder, followed by $50 \%$ date powder with 12.02 $\%$ protein. However, the minimum protein (18.59 $\%$ ) was observed with $0 \%$ without date powder (control). It was found that $100 \%$ dates powder was optimum level for biscuits so far the protein. The LSD test demonstrated that the differences in protein different date powder levels were non-significantly $(\mathrm{P}>0.05)$.

Table 12: Effect of different ratio of date powders on protein $(\%)$ of biscuits

\begin{tabular}{|l|c|c|c|c|}
\hline Treatments & RI & RII & RIII & Mean \\
\hline T1 & 6.56 & 8.75 & 7.65 & $\mathbf{7 . 6 5} \mathbf{C}$ \\
\hline T2 & 13.12 & 10.93 & 12.02 & $\mathbf{1 2 . 0 2} \mathbf{~ B}$ \\
\hline T3 & 17.5 & 19.68 & 18.59 & $\mathbf{1 8 . 5 9} \mathbf{~ A}$ \\
\hline S.E. \pm & 3.2598 \\
LSD0,05 & 7.9765
\end{tabular}

$\mathrm{T} 1=0 \%$ without date powder (control);

$\mathrm{T} 2=50 \%$ date powder; $\mathrm{T} 3=100 \%$ dates powder

Carbohydrate: It is evident from the results that the maximum biscuits carbohydrate $(54.18 \%)$ was observed when the biscuits treated with $100 \%$ dates powder, followed by $50 \%$ date powder with $52.11 \%$ carbohydrate. However, the minimum carbohydrate $(44.37 \%)$ was observed with $0 \%$ without date powder (control). It was found that $100 \%$ dates powder was optimum level for biscuits so far the carbohydrate. The LSD test demonstrated that the differences in carbohydrate different date powder levels were non-significantly $(\mathrm{P}>0.05)$.

Table 13: Effect of different ratio of date powders on carbohydrate $(\%)$ of biscuits

\begin{tabular}{|c|l|l|l|l|}
\hline Treatments & RI & RII & RIII & Mean \\
\hline T1 & 56.10 & 52.27 & 54.19 & $\mathbf{5 4 . 1 8 A}$ \\
\hline T2 & 51.59 & 52.62 & 52.12 & $\mathbf{5 2 . 1 1 A}$ \\
\hline T3 & 44.24 & 44.51 & 44.38 & $\mathbf{4 4 . 3 7 B}$ \\
\hline S.E. \pm & 1.0673 \\
LSD0.05 & \multicolumn{5}{|c}{2.9633}
\end{tabular}

$\mathrm{T} 1=0 \%$ without date powder; (control)

$\mathrm{T} 2=50 \%$ date powder; $\quad \mathrm{T} 3=100 \%$ dates powder
Overall acceptability: Overall acceptability results shows that the maximum score of overall aceptability was noted (8.06) when the biscuits treated with $100 \%$ dates powder, followed by $50 \%$ date powder with 7.56 overall acceptability. However, the minimum overall acceptability (6.60) was observed with $0 \%$ without date powder (control). It was found that $100 \%$ dates powder was optimum level for biscuits so far the overall acceptability. The LSD test demonstrated that the differences in overall acceptability different date powder levels were non-significantly $(\mathrm{P}>0.05)$.

Table 14: Effect of different ratio of date powders on overall acceptability of biscuits

\begin{tabular}{|l|c|c|c|c|}
\hline Treatments & RI & RII & RIII & Mean \\
\hline T1 & 6.8 & 6.6 & 6.4 & $\mathbf{6 . 6 0 ~ C}$ \\
\hline T2 & 7.6 & 7.3 & 7.8 & $\mathbf{7 . 5 6 ~ B ~}$ \\
\hline T3 & 8.0 & 7.9 & 8.3 & $\mathbf{8 . 0 6}$ A \\
\hline S.E. \pm & 0.1816 \\
LSD 0.05 & \multicolumn{5}{|c}{0.5041}
\end{tabular}

$\mathrm{T} 1=0 \%$ without date powder (control);

$\mathrm{T} 2=50 \%$ date powder

T3 $=100 \%$ dates powder

\section{DISCUSION}

Biscuits have always been one of the most popular food items due to their taste, textural characteristics, compactness, convenience and cost competitiveness, and have lower moisture content from cakes and bread, and generally safer from microbiological spoilage and have a longer shelf life (Singh and Dhandar, 2007).

The biscuits treated with $100 \%$ dates powder resulted $3.65 \%$ moisture, $0.69 \%$ ash, $11.71^{\circ} \mathrm{Brix}$ total soluble solids, $5.70 \mathrm{pH}$ value, $20.68 \mathrm{mg} /$ $100 \mathrm{~g}$ vitamin $\mathrm{C}, 34.19 \%$ fat, 0.04 per $100 \mathrm{mg}$ crude fiber, $7.65 \%$ protein, $54.18 \%$ carbohydrate, 8.36 color, 8.60 flavor, 7.86 texture, 8.50 taste and 8.06 overall acceptability. Similarly, the biscuits with $50 \%$ date powder resulted $2.92 \%$ moisture, $0.36 \%$ ash, $9.72^{\circ}$ Brix total soluble solids, $5.63 \mathrm{pH}$ value, $20.68 \mathrm{mg} / 100 \mathrm{~g}$ vitamin c, $33.79 \%$ fat, 0.03 per $100 \mathrm{mg}$ crude fiber, $12.02 \%$ protein, $52.11 \%$ carbohydrate, 7.46 color, 7.53 flavor, 7.60 texture, 7.46 taste and 7.56 overall acceptability. The date powder $0 \%$ without date powder (control) resulted in $2.44 \%$ moisture, $0.30 \%$ ash, $9.50^{\circ}$ Brix total soluble solids, $5.60 \mathrm{pH}$ value, $16.92 \mathrm{mg} / 100 \mathrm{~g}$ vitamin $\mathrm{C}$, $32.61 \%$ fat, 0.02 per $100 \mathrm{mg}$ crude fiber, $18.59 \%$ protein, $44.37 \%$ carbohydrate, 6.26 color, 6.63 flavor, 6.56 texture, 6.46 taste and 6.60 which is overall acceptability. It is concluded from the study that the biscuits treated with Treatment-3 100 $\%$ date powder shown better effect on quality of biscuits, and physico-chemical parameters. It is 
also concluded that date powder enriched biscuits are safe than sucrose added biscuits for diabetes people. The results were in accordance with Fahloul et al., (2010) who mentioned that by increasing of date powder levels the biscuit hardness values was decreased. Khouryieh and Aramouni (2012) mentioned that the biscuit hardness is related to the development of gluten and the interaction with flour ingredients in the formula is acceptable at 30\% mixture. The appearance, taste and flavor of biscuits under T1 and T2 were good even after 30 days of storage. The acceptability of biscuits gradually decreased with increasing period of storage because of taste sensation after one month period. This may be possibly due to the chemical reactions in carbohydrates and fats of the products. During storage, changes in physico-chemical characters are common in any value added product. The finding is similar with the results reported by Singh and Dhandar (2007).

\section{Conclusion}

- It is concluded from the study that the biscuits treated with $\mathrm{T} 3100 \%$ date powder shown better effect on quality of biscuits, and physicochemical parameters.

- It is also concluded that date powder enriched biscuits are safe than sucrose added biscuits for diabetes people.

\section{Suggestions}

- It is suggested that biscuits enriched with date powder are nutritious for better health, good in taste and less sweetener than common sugar biscuits

- It is suggested from this study that replacement of date powder enriched biscuits can be recommended for patients of diabetes in order to decrease the intake of common table sugar.

\section{REFERENCES}

Abdel, F., E. Sulieman, M.K. Masaad and A.O. Ali, Effect of partial substitution of wheat flour with date powder on biscuit quality. Journal of Food Processing Technology 89 (2): 569-578 (2017).

Abioye, F., A.J.A. Adeyanju and Z.O. Kareem, Production and quality evaluation of biscuits produced from date powder. Journal of Advances in Food Sci and Technol. 13(3): 129135 (2015).

Alsenaien, W.A., R.A. Alamer, R.A., Z. hen-Xing Tang, S.A. Albahrani, S.A., Al-Ghannam, M. A. and S. M. Aleid, Substitution of sugar with dates powder and dates syrup in cookies making. Advance Journal of Food Science and Technology 8: 8-13 (2015).

Anis, M.Z., W.I. Jauharah, W. Wan and S.D.
Robert, Physicochemical and Sensorial Evaluation of Biscuit and Muffin Incorporated with Date powder. J. of Agri Sci. 43(1): 4552 (2014).

Anwarul, H., U. Shams and A. Anwarul, The effect of aqueous extracted wheat bran on the baking quality of biscuit. International Journal of Food Science and Technology 37(2): 453-462 (2012).

AOAC. 2000. Official method of analysis of the association of the analytical chemists. Inc. Virginia. USA.

Ashok, K., R. Shrestha and A. Noomhorm, Comparison of physico-chemical properties of biscuits supplemented with soy and date chemical powder. International J. of Food Sci and Techneol. 65(3): 674-935 (2012).

Ayo, J.A. and E. Andrew, Effect of added Bambara groundnut on the quality of acha-date palm based biscuit. International Journal of Biotechnology and Food Science 14(3): 3438 (2016)

Azouz, A., Nutritional evaluation of children meals at Egyptian schools: II - Amino acids, minerals and vitamins profiles. Ann. Agric. Sci. 56: 77-81 (2016).

Cauvain, S.P. and K.S. Young, The Nature of Baked Product Structure. Oxford, England: Blackwell Publishing 33(9): 389-526 (2007)

Chandra, A., C. Anju and I.C. Gupta, Date Palm Research in Thar Desert.Scientific Publisher, Jodhpur 36(6): 576-632 (2012)

El-Sharnouby, A.G., S.M. Aleid, S.M. and M.M. Al-Otaibi., Nutritional quality of biscuit supplemented with wheat bran and date palm fruits (Phoenix dactylifera L.). Journal of Food and Nutrition Sciences 3: 322-328 (2012).

Fahloul, D., M. Abdedaim and G. Trystram, Heat, mass transfer and physical properties of biscuits enriched with date powder. Journal of Applied Sciences Research 6(1): 1680-1686 (2018)

Fahloul, D., M. Abdedaim, M. and G. Trystram, Heat, mass transfer and physical properties of biscuits enriched with date powder. Journal of Applied Sciences Research 6: 1680-1686 (2010).

Gama, A., El-Sharnouby, S.M. Aleid and M.M. Al-Otaibi, Nutritional Quality of Biscuit Supplemented with Wheat Bran and Date Palm Fruits (Phoenix dactylifera L.). Food and Nutrition Sciences 13(2): 322-328 (2017).

Hashem, H.A., M.M. Abu-Fadl and A.G. Nassar, Effect of Replacement of Wheat Flour by Jerusalem Arti-choke Flour on Dough Rheological Properties and Quality off Biscuit 
Produced, Bulletin of the National Nutrition Institute, Cairo, Egypt 25(2): 198-218 (2004).

Helen, R., O. Agu and N.A. Okoli, Physic-chemical, sensory, and microbiological assessments of date powder biscuit improved with beniseed and unripe plantain. J. of Food Sci. 98(2): 665-675 (2014).

Hoseney, R.C., "Principles of Cereal Science and Technology," American Association of Cereal Chemists (PUP), Pilot Knob Road, St. Paul. 20(2): 245-261 (2014).

James, C.S., Analytical chemistry of food. SealeHayne faculty of agric. Food and land use, Dep. of Agric. and Food studies, Uni. Polymouth, UK 1: 96- 97 (1995).

Kajal, M.F.I., A. Wadud, M.N. Islam and P.K. Sarma1, Evaluation of some chemical parameters of powder milk available in Mymensingh town. J. Bangladesh Agril. Univ. 10(2): 95-100 (2012).

Khaled, M., Al-Marazeeq and M.M. Angor, Chemical characteristic and sensory evaluation of biscuit enriched with date powder and the effect of storage time on the sensory properties for this product. J. of Food Sci. 98(2): 158-165 (2015).

Khouryieh, H. and F. Aramouni, Physical and sensory characteristics of cookies prepared with flaxseed flour. Journal Science Food Agriculture 92: 2366-2372 (2012).

Larmond. E., Laboratory methods for sensory evalution of foods, ottawa, Dep.Agri. Pub. Pp. 1637-1674 (1977).

Marisa, R., T. Beatriz, K. Vázquez, A. Curia and G. Hough, Sensory descriptive analysis, sensory acceptability and expectation studies on biscuits with reduced added salt and increased date powder. J. of Sensory Studies 24(4): 419-426 (2013).

Mazumdar, B.C. and K. Majumder, Methods on physicochemical analysis of fruits. Uni. College of Agric. Calcutta Uni., 108-109 (2003).

Mishra, N. and R. Chandra, Development of functional biscuit from soy flour and rice bran. IJAFST 2: 14-20 (2012).

Mohamed, A.K., F.A.H. El Sokkary, N. Mohammed, T.A. Mostafa and Zeinab. A. Galil, Chemical, physical and sensory evaluation of biscuit supplemented with date powder. Minia J. of Agric. Res. And Develop 36(2): 215-227 (2016).

Muralidharan, C.M., S.B.S. Tikka and V. Piyush, Date palm Cultivation in Kachchh, Technical Bulletin-2, Date palm Research Station, SDAU, Mundra, Pp. 36 (2008).

Norimah, A.K., M. Safiah, K. Jamal, S. Haslinda,
H. Zuhaida, S. Rohida, S. Fatimah,, S. Norazlin, B.K. Poh, M. Kandiah, M. S. Zalilah, W. Manan, W. Fatimah and S. Azmi, Food Consumption Patterns: Findings from the Malaysian Adult Nutrition Survey (MANS). Malaysian J. of Nutrition 14(1): 25-39 (2008).

Obaroakpo, J.U., I. Iwanegbe and A. Ojokoh, The functional and sensory evaluation of biscuits produced from wheat, defatted soybean and date powder. Current J. of Applied Sci and Technol. 23(4): 1-7 (2017).

Rathore, R., G. Madhu and D. Vimla, Commercial potential of date fruits for the formulation of mouth fresheners in arid areas. In Souvenir, National Seminar on Agri-Business Potential of Rajasthan, IABM, SKRAU, Bikaner, Pp. 87, 19-20 March (2013).

Singh, R.S. and D.G. Dhandar, Khajoor Ki Kheti, Bulletin, Directorate of Extension. Ministry of Agriculture, Government of India, New Delhi. 22: 27-66 (2007).

Steel, R., J. Torrie and D. Dickey, Principles and Procedures of Statistics. A Biometrical Approach, 3rd Ed., McGraw Hill Book Co., New York, NY (1997).

Sudha, M.L., R. Vetrimani and K. Leelavathi, Influence of Fibre from Different Cereals on the Rheological Characteristics of Wheat Flour Dough and on Biscuit Quality. Food Chemistry 10(4): $1365-1370$ (2007).

Sulieman, A.E., M.K. Masaad and O.A. Ali, Effect of partial substitution of wheat flour with date powder on biscuit quality. Journals of University of Gezira 9(1): 119-116 (2012).

Tugba, O., B. Karakaş and F. Yildiz, Sensory and textural evaluation of gluten-free biscuits containing date powder flour. J. of Applied Sci. 11(2): 1196-1203 (2016).

Usman, G.O., U.E. Ameh and R.M. Babatunde, Proximate composition of biscuits produced from wheat flour and maize bran composite flour fortified with carrot extract. J. Nutr. Food. Sci. 5: 1-2 (2015).

Vinita, T., R. Darshan and J. Punia, Sensory characteristics and nutrient composition of biscuits prepared by using seed powder of date fruit. International J. of Food Sci. and Nutrition 12(2): 120-128 (2017). 